\title{
Performance of Agro-Based Industries in India: A Critical Analysis
}

\author{
*C.Lakshmi kantha reddy, **Prof S.Rathna kumari, \\ Research Scholar,S.V.University, Tirupathi- \\ dept of Economics, S.V. University, Tirupathi-517502 A.P.
}

\section{Introduction}

Agriculture has been a way of life and continues to be the single most important livelihood of the masses. Agricultural policy focus in India across decades has been on self-sufficiency and self-reliance in food grains production. Considerable progress has been made on this front. Food grains production rose from 52 million tonnes in 1951-52 to 244.78 million tonnes in 2010-11. The share of agriculture in real GDP has fallen given its lower growth rate relative to industry and services. However, what is of concern is that growth in the agricultural sector has quite often fallen short of the Plan targets. During the period 1960-61 to 2010-11, food grains production grew at a compounded annual growth rate (CAGR) of around 2 per cent. In fact, the Ninth and Tenth Five Year Plans witnessed agricultural sectoral growth rate of 2.44 per cent and 2.30 per cent respectively compared to 4.72 per cent during Eighth Five Year Plan. During the current Five Year plan, agriculture growth is estimated at 3.28 per cent against a target of 4 per cent. The Approach Paper to the Twelfth Five Year Plan emphasizes the need to "redouble our efforts to ensure that 4.0 per cent average growth" is achieved during the Plan if not more. Without incremental productivity gains and technology diffusion across regions, achieving this higher growth may not be feasible and has implications for the macroeconomic stability given the rising demand of the 1.2 billion people for food. Achieving minimum agricultural growth is a pre-requisite for inclusive growth, reduction of poverty levels, development of the rural economy and enhancing of farm incomes.

Agriculture including allied activities, accounted for 14.5 per cent of gross domestic product (GDP) at 2004-05 prices, in 2010-11 as compared to 14.7 per cent in 2009-10. Notwithstanding the declining trend in agriculture's share in the GDP, it is critical from the income distribution perspective as it accounted for about 58 per cent employment in the country according to Census 2001 . Hence growth in agriculture and allied sectors remains a 'necessary condition' for inclusive growth. In terms of composition, out of the total share of 14.5 per cent that agriculture and allied sectors had in GDP in 2010-11, agriculture alone accounted for 12.3 per cent, followed by forestry and logging at 1.4 percent and fishing at 0.7 per cent . Reasonable growth in agriculture is important both from the nutritional point of view as well as to control food prices and overall headline inflation.

The place of the agro-based industries in the development of India is widely recognized and needs no emphasis. They can provide vast employment opportunities at comparatively low investment. The techniques of production adopted by the agro-based industries are simple and the machinery and equipment required by them is easily available.

The share of all agro-based industries in India account for 35.3 per cent of the total industrial units in India 40.32 per cent share of total employment and 21.69 of the total value of industrial output, and 15.18 per cent of the net value added during the year 2010-11. The percentage of working capital, fixed capital and net income of agro-based industries to total industries is 21.26 per cent, 20.3 per cent and 13.96 per cent respectively.

\section{Category-wise Agro-Based Industries in India}

\section{Performance Of Agro-Based Industries}

The total number of agro-based industries has increased from 28,584 in 2006-07 to 30,514 in 2011-12 with only 0.38 per cent growth rate.

The manufacture of food products and beverages accounts for more than half of the total output of agro-based industries in India. Under this category, the manufacture of grain mill products, starches and starch products and prepared animal feeds is playing a prominent role with a share of 53 per cent.

The number of textile manufacturing units has the highest percentage next to food products and beverages, put their number has decreased slightly from 2006-07 to 2011-12, due to the continuous decrease in spinning, weaving and finishing of textiles from 27.25 per cent in 2006-07 to 26.68 per cent in 2011-12. The manufacture of leather products also shows the same trend during the period under study. This is presented in the diagram 4.1 . 
In the case of manufacture of food products and beverages, the Compound Growth Rate (CGR) is 5.10 per cent for both beverages, and dairy products and it is 0.48 per cent only for manufacture of other food products category.

The CGR is computed for the different categories of agro-based industries, which are significant at 5 per cent level, except 3(c) i.e. manufacture of knitted and crocheted fabrics and articles

CATEGORY-WISE AGRO-BASED INDUSTRIES IN INDIA

\begin{tabular}{|c|c|c|c|c|c|c|c|c|c|}
\hline $\begin{array}{l}\mathbf{S} \\
\dot{\mathbf{N}}\end{array}$ & Category & 2006-07 & 2007-08 & 2008-09 & 2009-10 & $2010-11$ & 2011-12 & CGR & t-Stat \\
\hline \multirow[t]{6}{*}{1} & $\begin{array}{l}\text { Manufacture of food } \\
\text { products \& Beverages }\end{array}$ & $\begin{array}{c}25,584 \\
(52.59)\end{array}$ & $\begin{array}{l}24,238 \\
(51.56)\end{array}$ & $\begin{array}{l}28,547 \\
(53.29)\end{array}$ & $\begin{array}{l}28,654 \\
(52.40)\end{array}$ & $\begin{array}{l}29,874 \\
(52.21)\end{array}$ & $\begin{array}{l}30,510 \\
(51.86)\end{array}$ & 2.19 & $48.52^{*}$ \\
\hline & $\begin{array}{c}\text { a) Production, } \\
\text { Processing \& } \\
\text { Preservation of Meat, } \\
\text { Fish, Fruit, Oil \& Fats }\end{array}$ & 3,951 & 4,012 & 4,258 & 4,426 & 4,897 & 5,019 & 1.40 & $14.12^{*}$ \\
\hline & $\begin{array}{l}\text { b) Manufacture of Dairy } \\
\text { Products }\end{array}$ & 758 & 795 & 851 & 924 & 874 & 963 & 5.10 & $31.00^{*}$ \\
\hline & $\begin{array}{l}\text { c) Manufacture of Grain } \\
\text { Mill Products, Starches } \\
\text { \& Starch Products and } \\
\text { Prepared Animal Feeds }\end{array}$ & 12,852 & 12,985 & 12,987 & 13,520 & 13,285 & 14,021 & 2.30 & $47.29^{*}$ \\
\hline & $\begin{array}{l}\text { d) Manufacture of Other } \\
\text { Food Products }\end{array}$ & 5,874 & 5,044 & 5,921 & 6,012 & 6,623 & 7,215 & 0.48 & $25.36^{*}$ \\
\hline & $\begin{array}{l}\text { e) Manufacture of } \\
\text { Beverages }\end{array}$ & 2149 & 1402 & 4530 & 3772 & 4195 & 3292 & 4.19 & $14.87^{*}$ \\
\hline 2 & $\begin{array}{l}\text { Manufacture of } \\
\text { Tobacco products }\end{array}$ & $\begin{array}{l}2,952 \\
(6.06)\end{array}$ & $\begin{array}{l}2,541 \\
(5.40)\end{array}$ & $\begin{array}{c}3845 \\
(7.17)\end{array}$ & $\begin{array}{c}3785 \\
(6.92)\end{array}$ & $\begin{array}{l}4,136 \\
(7.22)\end{array}$ & $\begin{array}{l}4,157 \\
(7.06)\end{array}$ & 5.76 & $5.59^{*}$ \\
\hline \multirow[t]{4}{*}{3} & $\begin{array}{l}\text { Manufacture of } \\
\text { Textiles }\end{array}$ & $\begin{array}{l}\mathbf{1 3 , 5 0 2} \\
(27.25)\end{array}$ & $\begin{array}{l}13,852 \\
(29.47)\end{array}$ & $\begin{array}{l}14,251 \\
(26.60)\end{array}$ & $\begin{array}{l}14,988 \\
(27.40)\end{array}$ & $\begin{array}{l}15,654 \\
(27.36)\end{array}$ & $\begin{array}{l}15,698 \\
(26.68)\end{array}$ & 0.31 & $55.56^{*}$ \\
\hline & $\begin{array}{l}\text { a) Spinning, Weaving \& } \\
\text { Finishing Textiles }\end{array}$ & 9,855 & 9,962 & 10,542 & 10,854 & 10,995 & 11,023 & 1.73 & $41.47^{*}$ \\
\hline & $\begin{array}{l}\text { b) Manufacture of Other } \\
\text { Textiles }\end{array}$ & 1,110 & 1,230 & 1,452 & 1,362 & 1,487 & 1,464 & 5.85 & $2.80^{*}$ \\
\hline & $\begin{array}{l}\text { c) Manufacture of } \\
\text { Knitted and Crocheted } \\
\text { Fabrics and Articles }\end{array}$ & 2,537 & 2,660 & 2,257 & 2,772 & 3,172 & 3,211 & 5.4 & $0.421^{*}$ \\
\hline \multirow[t]{3}{*}{4} & $\begin{array}{c}\text { Manufacture of } \\
\text { Leather Products }\end{array}$ & $\begin{array}{l}2,654 \\
(5.45) \\
\end{array}$ & $\begin{array}{l}2,842 \\
(6.04) \\
\end{array}$ & $\begin{array}{l}2,956 \\
(5.51) \\
\end{array}$ & $\begin{array}{l}3,241 \\
(5.92) \\
\end{array}$ & $\begin{array}{l}3,420 \\
(5.97)\end{array}$ & $\begin{array}{l}3,896 \\
(6.62) \\
\end{array}$ & 3.72 & $3.14^{*}$ \\
\hline & $\begin{array}{l}\text { a) Manufacture of hats } \\
\text { and caps from } \\
\text { waterproof }\end{array}$ & 1,522 & 1,634 & 1,752 & 1,960 & 2,101 & 2,055 & 2.41 & $32.52^{*}$ \\
\hline & $\begin{array}{c}\text { b) Manufacture of } \\
\text { wearing apparel of } \\
\text { leather and substitutes of } \\
\text { leather }\end{array}$ & 1,132 & 1,208 & 1,204 & 1,281 & 1,319 & 1,841 & 4.75 & $4.15^{*}$ \\
\hline \multirow[t]{2}{*}{5} & $\begin{array}{c}\text { Manufacture of Paper } \\
\text { \& Paper Products }\end{array}$ & $\begin{array}{c}3954 \\
(8.12)\end{array}$ & $\begin{array}{c}3529 \\
(7.50)\end{array}$ & $\begin{array}{c}3966 \\
(7.40)\end{array}$ & $\begin{array}{l}4013 \\
(7.33)\end{array}$ & $\begin{array}{c}4124 \\
(7.20)\end{array}$ & $\begin{array}{l}4568 \\
(7.76)\end{array}$ & 2.49 & $22.28^{*}$ \\
\hline & Total & $\begin{array}{c}48,646 \\
(100.00)\end{array}$ & $\begin{array}{l}47,002 \\
(100.00)\end{array}$ & $\begin{array}{c}53,565 \\
(100.00)\end{array}$ & $\begin{array}{c}54,681 \\
(100.00)\end{array}$ & $\begin{array}{c}57,208 \\
(100.00)\end{array}$ & $\begin{array}{c}\mathbf{5 8 , 8 2 9} \\
(100.00)\end{array}$ & 1.55 & $71.57^{*}$ \\
\hline
\end{tabular}

(Table value $=2.306) *$ Significant at 5 per cent level@ Not significant at 5 per cent level

Note : Percentages in parentheses 2. www.indiastat.com

Source: 1. Annual Survey of Industries, Central Statistical Organisation, New Delhi. (Different issues)

\section{CATEGORY-WISE AGRO-BASED INDUSTRIES IN INDIA}

(Number of Units)

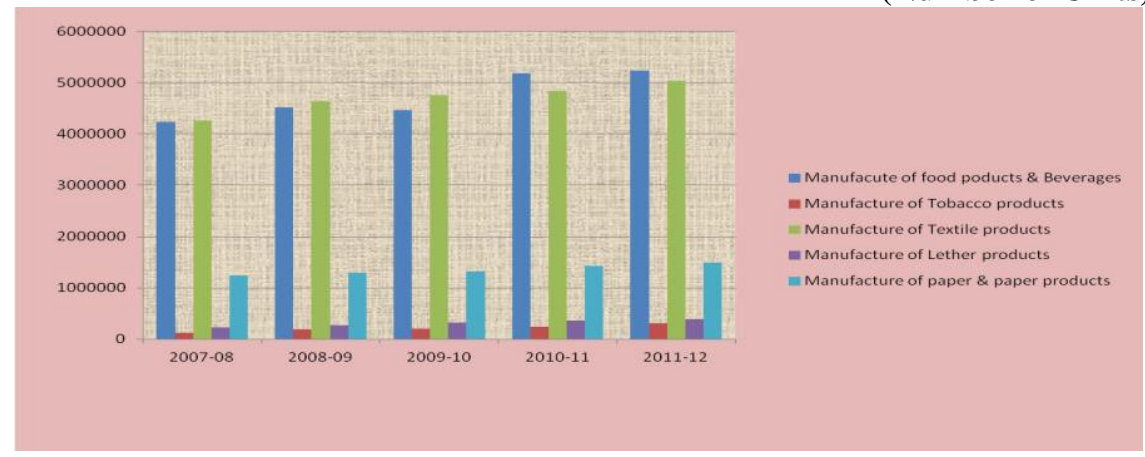

Source: 1. Annual Survey of Industries, Central Statistical Organisation, New Delhi. (Different issues).

2. www.indiastat.com 


\section{Category wise Fixed Capital of Agro-Based Industries}

Fixed capital refers to any kind of real or physical capital (fixed asset) that is not used up in the production of a product. Fixed capital is that portion of the total capital which is invested in fixed assets (such as land, buildings, vehicles and equipment) which stay in the business almost permanently.

The fixed capital of total agro-based industries has increased by 15.29 per cent from Rs.60,00,682 lakhs in 2007-08 to Rs.77,13,367 lakhs in 2011-12.

The fixed capital was the highest in the case of manufacture of textile industry during the period 200708 to 2011-12 compared to other categories of agro-based industries, but its share has been decreasing from 42.25 per cent to 40.42 per cent. The manufacture of food products and beverages is occupying second place in fixed capital investment and its share in total agro-based industries is almost the same i.e., 42 per cent during the period under study except 2007-08. The share of fixed capital in the case of tobacco products is the lowest in all the years of the study. The same is shown in diagram 1.2.

The Compound Growth Rate (CGR) is calculated for all the categories of agro-based industries based on the data available in Table 4.2. The CGR is the highest in manufacture of food products and beverages and the lowest in the manufacture of leather products, but compound growth rate of all the categories of agro-based industries is significant at 1 per cent level

\section{CATEGORY-WISE FIXED CAPITAL OF AGRO-BASED INDUSTRIES} IN INDIA

\begin{tabular}{|c|c|c|c|c|c|c|c|c|}
\hline & \\
\hline $\begin{array}{l}\text { Sl } \\
\text { No }\end{array}$ & Category & 2007-08 & 2008-09 & 2009-10 & 2010-11 & 2011-12 & CGR & t-Stat \\
\hline \multirow[t]{6}{*}{1} & $\begin{array}{l}\text { Manufacture of food } \\
\text { products \& Beverages }\end{array}$ & $\begin{array}{c}42,32,654 \\
(41.91)\end{array}$ & $\begin{array}{c}\mathbf{4 5 , 2 1 , 8 7 4} \\
(41.47) \\
\end{array}$ & $\begin{array}{c}44,64,852 \\
(40.37) \\
\end{array}$ & $\begin{array}{c}\mathbf{5 1 , 8 4 , 6 4 5} \\
(43.01)\end{array}$ & $\begin{array}{c}52,32,874 \\
(42.04)\end{array}$ & 4.27 & $21.65^{*}$ \\
\hline & $\begin{array}{l}\text { a) Production, Processing } \\
\& \text { Preservation of Meat, } \\
\text { Fish, Fruit, Oil \& Fats }\end{array}$ & $7,23,987$ & $7,98,745$ & $8,25,321$ & $9,64,951$ & $9,36,254$ & 5.24 & $17.86^{*}$ \\
\hline & $\begin{array}{l}\text { b) Manufacture of Dairy } \\
\text { Products }\end{array}$ & $2,64,845$ & $2,98,632$ & $3,52,413$ & $3,69,699$ & $4,25,320$ & 3.54 & $36.54^{*}$ \\
\hline & $\begin{array}{l}\text { c) Manufacture of Grain } \\
\text { Mill Products, Starches \& } \\
\text { Starch Products and } \\
\text { Prepared Animal Feeds } \\
\end{array}$ & $4,65,213$ & $4,98,741$ & $4,83,987$ & $5,21,632$ & $7,35,258$ & 6.01 & $14.87^{*}$ \\
\hline & $\begin{array}{l}\text { d) Manufacture of Other } \\
\text { Food Products }\end{array}$ & $18,32,635$ & $18,94,201$ & $19,13,235$ & $19,87,987$ & $20,64,852$ & 4.75 & $22.41^{*}$ \\
\hline & $\begin{array}{l}\text { e) Manufacture of } \\
\text { Beverages }\end{array}$ & $9,45,974$ & $10,31,555$ & $8,89,896$ & $13,40,376$ & $10,71,190$ & 8.97 & $16.82^{*}$ \\
\hline 2 & $\begin{array}{l}\text { Manufacture of Tobacco } \\
\text { products }\end{array}$ & $\begin{array}{c}1,21,541 \\
(1.20)\end{array}$ & $\begin{array}{c}1,85,029 \\
(1.69)\end{array}$ & $\begin{array}{c}1,98,200 \\
(1.79)\end{array}$ & $\begin{array}{l}2,44,760 \\
(2.03)\end{array}$ & $\begin{array}{c}3,02,494 \\
(2.43) \\
\end{array}$ & 2.35 & $30.64^{*}$ \\
\hline \multirow[t]{4}{*}{3} & Manufacture of Textiles & $\begin{array}{c}42,66,982 \\
(42.25)\end{array}$ & $\begin{array}{c}46,32,589 \\
(42.28)\end{array}$ & $\begin{array}{c}\mathbf{4 7 , 5 2 , 2 2 1} \\
(\mathbf{4 2 . 9 7 )}\end{array}$ & $\begin{array}{c}48,35,552 \\
(40.12)\end{array}$ & $\begin{array}{c}50,31,667 \\
(40.42)\end{array}$ & 1.39 & 33.87" \\
\hline & $\begin{array}{l}\text { a) Spinning, Weaving \& } \\
\text { Finishing Textiles }\end{array}$ & $36,98,554$ & $39,56,412$ & $41,25,987$ & $42,56,325$ & $42,98,758$ & 0.24 & $36.54^{*}$ \\
\hline & $\begin{array}{l}\text { b) Manufacture of Other } \\
\text { Textiles }\end{array}$ & $3,55,326$ & $3,69,698$ & $3,12,325$ & $3,56,921$ & $4,98,696$ & 10.98 & $12.37^{*}$ \\
\hline & $\begin{array}{l}\text { c) Manufacture of Knitted } \\
\text { and Crocheted Fabrics and } \\
\text { Articles }\end{array}$ & $2,13,102$ & $3,06,479$ & $3,13,909$ & $2,22,306$ & $2,34,213$ & 15.24 & $7.54^{*}$ \\
\hline \multirow[t]{3}{*}{4} & $\begin{array}{l}\text { Manufacture of Leather } \\
\text { Products }\end{array}$ & $\begin{array}{c}2,32,332 \\
(2.31)\end{array}$ & $\begin{array}{c}2,65,445 \\
(2.43)\end{array}$ & $\begin{array}{c}3,23,023 \\
(2.92)\end{array}$ & $\begin{array}{c}3,65,002 \\
(3.02)\end{array}$ & $\begin{array}{c}\text { 3,90,805 } \\
(3.14) \\
\end{array}$ & 0.71 & $55.77^{*}$ \\
\hline & $\begin{array}{l}\text { a) Manufacture of hats and } \\
\text { caps from waterproof }\end{array}$ & 87,668 & 88,231 & 89,230 & 95,325 & 95,236 & 6.03 & $20.38^{*}$ \\
\hline & $\begin{array}{l}\text { b) Manufacture of wearing } \\
\text { apparel of leather and } \\
\text { substitutes of leather }\end{array}$ & $1,44,664$ & $1,77,214$ & $2,33,793$ & $2,69,677$ & $2,95,569$ & 2.45 & $26.58^{*}$ \\
\hline \multirow[t]{2}{*}{5} & $\begin{array}{l}\text { Manufacture of Paper \& } \\
\text { Paper Products }\end{array}$ & $\begin{array}{c}12,44,501 \\
(12.32)\end{array}$ & $\begin{array}{c}\text { 12,98,236 } \\
(11.90)\end{array}$ & $\begin{array}{c}13,21,003 \\
(11.94)\end{array}$ & $\begin{array}{c}14,22,554 \\
(11.80)\end{array}$ & $\begin{array}{c}14,88,235 \\
(11.95)\end{array}$ & 2.33 & $22.88^{*}$ \\
\hline & Total & $\begin{array}{l}1,00,98,010 \\
(100.00)\end{array}$ & $\begin{array}{l}1,09,03,173 \\
(100.00)\end{array}$ & $\begin{array}{c}1,10,59,299 \\
(100.00)\end{array}$ & $\begin{array}{c}1,20,52,513 \\
(100.00)\end{array}$ & $\begin{array}{c}1,24,46,075 \\
(100.00)\end{array}$ & 4.21 & 33.49* \\
\hline
\end{tabular}

Note : Percentages in parentheses (Table ' $t$ ' value $=2.145) \quad *$ Significant at 1 per cent level

Source: 1. Annual Survey of Industries, Central Statistical Organisation, New Delhi. (Different issues).

2. www.indiastat.com 


\title{
CATEGORY-WISE FIXED CAPITAL OF AGRO-BASED INDUSTRIES IN INDIA
}

\author{
(Rs. in Lakhs)
}

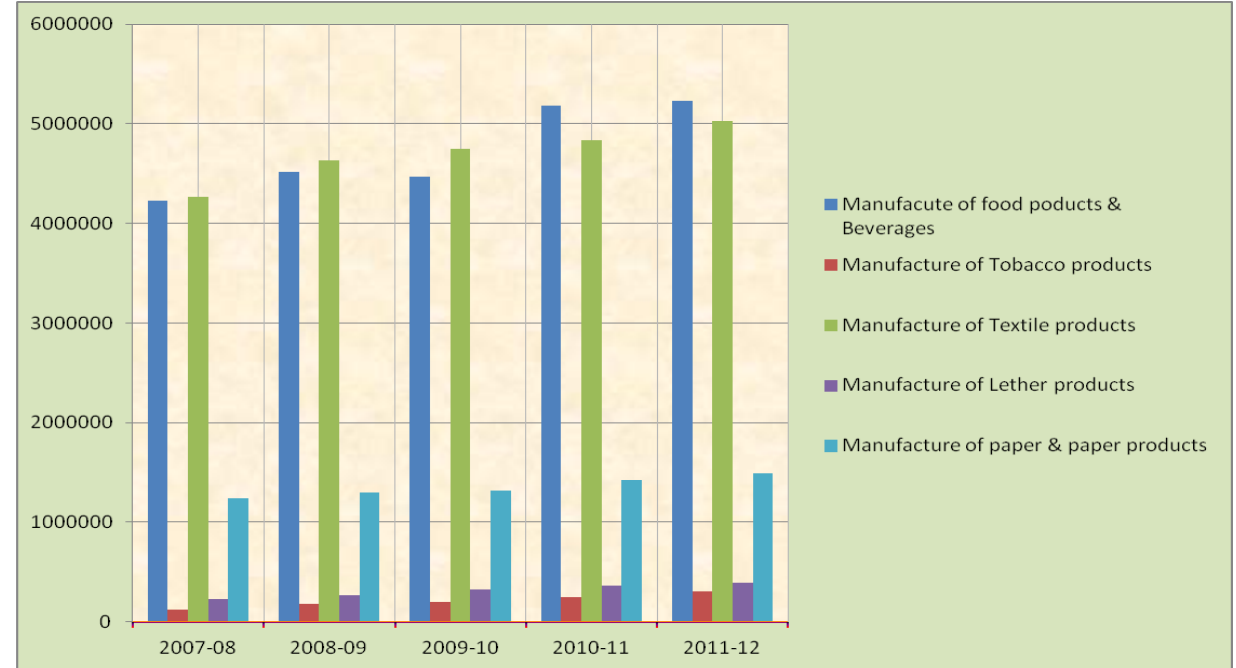

Source: 1. Annual Survey of Industries, Central Statistical Organisation, New Delhi. (Different issues).

2. www.indiastat.com

\section{Category-wise Working Capital of Agro-Based Industries}

Working Capital measures both a company's efficiency and its short-term financial health. The working capital ratio is calculated as: Working Capital $=$ Current Assets - Current Liabilities

Positive working capital means that the company is able to pay off its short-term liabilities. Negative working capital means that a company currently is unable to meet its short-term liabilities with its current assets (cash, accounts receivable and inventory). This is also known as "net working capital".

Over a period of five years, from 2000-01 to 2004-05, the working capital of total agro-based industries has increased from Rs. 24,02,002 lakhs to Rs. 34,03,200 lakhs with the growth of 41.68 per cent. Like fixed capital, the working capital investment is the highest in the case of manufacture of food products and beverages in all the five years.

The manufacture of textiles is occupying second place in working capital position and its share has been increasing from 33.91 per cent in 2007-08 to 33.41percent in 2010-11. Under the textile category, spinning, weaving, and finishing of textiles need more working capital compared to others. The category-wise working capital is shown in diagram 4.3.

The working capital position of tobacco products has gradually decreased from 5.37 per cent to 5.62 per cent and its share is the least in total agro-based industries. As per the Compound Growth Rate and tstatistic, all the categories of agro-based industries significant at 5 per cent level except manufacture of tobacco products

\section{Category-wise Employment in Agro-Based Industries}

Agro-based industries were providing employment to $12,65,122$ persons in 2007-08 and it increased to $14,10,102$ persons in 2011-12. It is observed from the Table 4.4 that among the different categories of agrobased industries, the manufacture of food products and beverages is providing the highest share of employment i.e. 38 per cent. The manufacture of textiles stood second by providing employment to the different persons (34.18 per cent). Compound Growth Rates are calculated for all the agro-based industries, which are significant at one per cent level. The employment levels are presented

CATEGORY -WISE WORKING CAPITAL OF AGRO-BASED INDUSTRIES IN INDIA (Rs. in Lakhs)

\begin{tabular}{|c|c|c|c|c|c|c|c|c|}
\hline SI. & Category & $\mathbf{2 0 0 7 - 0 8}$ & $\mathbf{2 0 0 8 - 0 9}$ & $\mathbf{2 0 0 9 - 1 0}$ & $\mathbf{2 0 1 0 - 1 1}$ & $\mathbf{2 0 1 1 - 1 2}$ & CGR & t-Stat \\
\hline $\mathbf{1}$ & $\begin{array}{c}\text { Manufacture of food } \\
\text { products \& Beverages }\end{array}$ & $\begin{array}{c}\mathbf{1 6 , 5 4 , 8 7 4} \\
\mathbf{( 4 7 . 9 7 )}\end{array}$ & $\begin{array}{c}\mathbf{1 6 , 8 5 , 9 7 8} \\
\mathbf{( 4 7 . 1 8 )}\end{array}$ & $\begin{array}{c}\mathbf{1 7 , 0 2 , 1 4 2} \\
\mathbf{( 4 6 . 3 5})\end{array}$ & $\begin{array}{c}\mathbf{1 7 , 5 4 , 2 3 1} \\
\mathbf{4 4 6 . 3 2})\end{array}$ & $\begin{array}{c}\mathbf{1 7 , 0 1 , 2 9 0} \\
(\mathbf{4 5 . 3 6})\end{array}$ & $\mathbf{1 . 6 5}$ & $\mathbf{7 6 . 5 4}$ \\
\hline & $\begin{array}{l}\text { a) Production, processing } \\
\text { \& Preservation of Meat, } \\
\text { Fish, Fruit, Oil \& Fats }\end{array}$ & $2,89,683$ & $2,95,789$ & $3,05,894$ & $3,74,100$ & $3,64,520$ & 4.51 & $22.43^{*}$ \\
\hline & $\begin{array}{c}\text { b) Manufacture of Dairy } \\
\text { Products }\end{array}$ & 92,100 & 95,654 & 98,569 & 94,603 & 98,578 & 0.42 & $67.98^{*}$ \\
\hline
\end{tabular}


Performance Of Agro-Based Industries In India: A Critical Analysis

\begin{tabular}{|c|c|c|c|c|c|c|c|c|}
\hline SI. & Category & 2007-08 & 2008-09 & 2009-10 & 2010-11 & 2011-12 & CGR & t-Stat \\
\hline & $\begin{array}{l}\text { c) Manufacture of Grain } \\
\text { Mill Products, Starches \& } \\
\text { Starch Products and } \\
\text { Prepared Animal Feeds }\end{array}$ & $6,89,231$ & $6,54,845$ & $7,12,542$ & $6,89,955$ & $6,86,300$ & 1.25 & $47.58^{*}$ \\
\hline & $\begin{array}{l}\text { d) Manufacture of Other } \\
\text { Food Products }\end{array}$ & $4,62,874$ & $4,65,744$ & $4,62,311$ & $4,86,566$ & $4,48,233$ & 1.91 & $63.91^{*}$ \\
\hline & $\begin{array}{l}\text { e) Manufacture of } \\
\text { Beverages }\end{array}$ & $1,20,986$ & $1,73,946$ & $1,22,826$ & $1,09,007$ & $1,03,659$ & 3.65 & $32.74^{*}$ \\
\hline 2 & $\begin{array}{c}\text { Manufacture of Tobacco } \\
\text { products }\end{array}$ & $\begin{array}{c}1,85,244 \\
(5.37) \\
\end{array}$ & $\begin{array}{c}1,64,100 \\
(4.59) \\
\end{array}$ & $\begin{array}{c}1,78,265 \\
(4.85) \\
\end{array}$ & $\begin{array}{c}1,65,988 \\
(4.38) \\
\end{array}$ & $\begin{array}{c}2,13,101 \\
(5.62) \\
\end{array}$ & 0.78 & $35.80^{*}$ \\
\hline \multirow[t]{4}{*}{3} & Manufacture of Textiles & $\begin{array}{c}11,69,899 \\
(33.91)\end{array}$ & $\begin{array}{c}12,54,620 \\
(35.11)\end{array}$ & $\begin{array}{c}12,45,231 \\
(33.91)\end{array}$ & $\begin{array}{c}12,87,568 \\
(34.00)\end{array}$ & $\begin{array}{c}\text { 12,82,147 } \\
(34.18)\end{array}$ & 0.14 & $55.19^{*}$ \\
\hline & $\begin{array}{l}\text { a) Spinning, Weaving \& } \\
\text { Finishing Textiles }\end{array}$ & $8,33,698$ & $8,56,344$ & $9,05,822$ & $9,45,121$ & $9,49,799$ & 2.81 & $40.54^{*}$ \\
\hline & $\begin{array}{l}\text { b) Manufacture of Other } \\
\text { Textiles }\end{array}$ & $1,65,644$ & $1,91,826$ & $2,10,005$ & $2,13,678$ & $2,17,922$ & 7.69 & $15.77^{*}$ \\
\hline & $\begin{array}{l}\text { c) Manufacture of Knitted } \\
\text { and Crocheted Fabrics } \\
\text { and Articles }\end{array}$ & $1,70,557$ & $2,06,450$ & $1,29,404$ & $1,28,769$ & $1,14,426$ & 19.13 & $6.86^{*}$ \\
\hline \multirow[t]{3}{*}{4} & $\begin{array}{c}\text { Manufacture of Leather } \\
\text { Products }\end{array}$ & $\begin{array}{c}1,86,522 \\
(5.40)\end{array}$ & $\begin{array}{c}1,94,009 \\
(5.42)\end{array}$ & $\begin{array}{c}2,47,588 \\
(6.74)\end{array}$ & $\begin{array}{c}2,55,855 \\
(6.75)\end{array}$ & $\begin{array}{c}2,43,789 \\
(6.50) \\
\end{array}$ & 6.71 & $17.58^{*}$ \\
\hline & $\begin{array}{l}\text { a) Manufacture of hats } \\
\text { and caps from waterproof }\end{array}$ & 53,309 & 55,236 & 56,429 & 59,244 & 59,388 & 0.31 & $80.37^{*}$ \\
\hline & $\begin{array}{l}\text { b) Manufacture of } \\
\text { wearing apparel of leather } \\
\text { and substitutes of leather }\end{array}$ & $1,33,213$ & $1,38,773$ & $1,91,159$ & $1,96,611$ & $1,84,401$ & 11.68 & $11.31^{*}$ \\
\hline \multirow[t]{2}{*}{5} & $\begin{array}{l}\text { Manufacture of Paper \& } \\
\text { Paper Products }\end{array}$ & $\begin{array}{c}2,52,654 \\
(7.32)\end{array}$ & $\begin{array}{c}2,74,285 \\
(7.62)\end{array}$ & $\begin{array}{c}2,98,653 \\
(8.13)\end{array}$ & $\begin{array}{c}\text { 3,22,987 } \\
(\mathbf{8 . 5 2})\end{array}$ & $\begin{array}{c}3,10,270 \\
(8.27)\end{array}$ & 0.20 & 88.10* \\
\hline & Total & $\begin{array}{c}34,49,193 \\
(100.00)\end{array}$ & $\begin{array}{c}35,72,992 \\
(100.00)\end{array}$ & $\begin{array}{c}36,71,879 \\
(100.00)\end{array}$ & $\begin{array}{c}37,86,629 \\
(100.00)\end{array}$ & $\begin{array}{c}\mathbf{3 7 , 5 0 , 5 9 7} \\
(\mathbf{1 0 0 . 0 0 )}\end{array}$ & 0.45 & $165.45^{*}$ \\
\hline
\end{tabular}

(Table't' value $=2.240) \quad *$ Significant at 5 per cent level@ @ Not significant at 5 per cent level

Note : Percentages in parentheses

Source: 1. Annual Survey of Industries, Central Statistical Organisation, New Delhi. (Different issues)

2. www.indiastat.com

CATEGORY -WISE WORKING CAPITAL OF AGRO-BASED INDUSTRIES IN INDIA (Rs. in Lakhs)

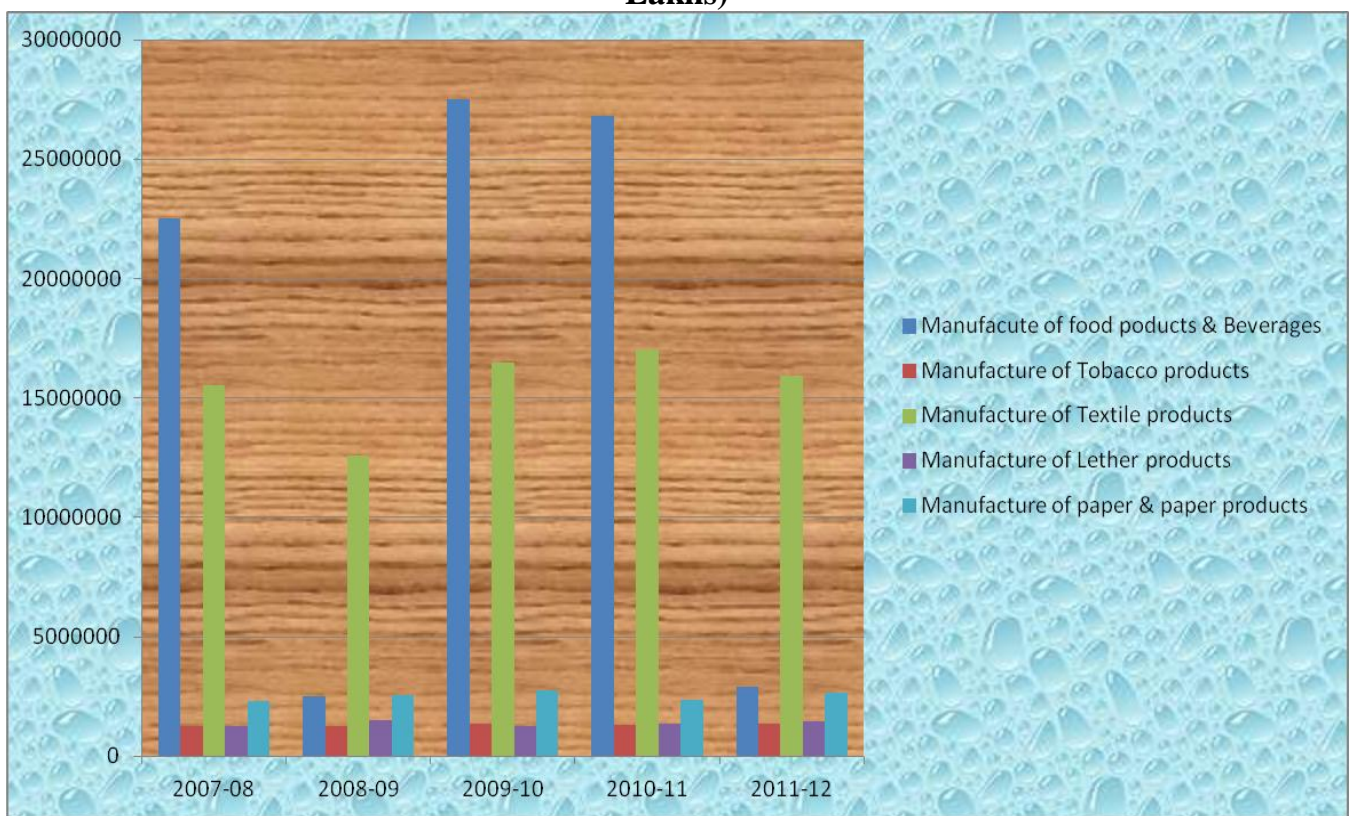

Source: 1. Annual Survey of Industries, Central Statistical Organisation, New Delhi. (Different issues).

2. www.indiastat.com 
Performance Of Agro-Based Industries In India: A Critical Analysis

CATEGORY-WISE EMPLOYMENT IN AGRO-BASED INDUSTRIES IN INDIA (Rs. in Lakhs)

\begin{tabular}{|c|c|c|c|c|c|c|c|c|}
\hline $\begin{array}{l}\text { Sl. } \\
\text { N } \\
\text { o. }\end{array}$ & Category & 2007-08 & 2008-09 & 2009-10 & 2010-11 & 2011-12 & CGR & t-Stat \\
\hline \multirow[t]{6}{*}{1} & $\begin{array}{l}\text { Manufacture of food } \\
\text { products \& } \\
\text { Beverages }\end{array}$ & $\begin{array}{c}12,65,122 \\
(38.03)\end{array}$ & $\begin{array}{c}13,45,623 \\
(38.70)\end{array}$ & $\begin{array}{c}13,75,844 \\
(38.76)\end{array}$ & $\begin{array}{c}\text { 13,98,570 } \\
(37.50)\end{array}$ & $\begin{array}{l}14,10,102 \\
(38.00)\end{array}$ & 1.32 & 90.05* \\
\hline & $\begin{array}{l}\text { a) Production, } \\
\text { Processing \& } \\
\text { Preservation of Meat, } \\
\text { Fish, Fruit, Oil \& } \\
\text { Fats }\end{array}$ & $1,54,677$ & $1,65,289$ & $2,05,100$ & $2,35,378$ & $2,78,600$ & 4.81 & $23.69 *$ \\
\hline & $\begin{array}{l}\text { b) Manufacture of } \\
\text { Dairy Products }\end{array}$ & 83,845 & 86,412 & 87,725 & 89,795 & 90,412 & 0.53 & $70.64^{*}$ \\
\hline & $\begin{array}{l}\text { c) Manufacture of } \\
\text { Grain Mill Products, } \\
\text { Starches \& Starch } \\
\text { Products and } \\
\text { Prepared Animal } \\
\text { Feeds }\end{array}$ & $3,34,126$ & $3,56,531$ & $3,64,120$ & $3,92,544$ & $4,10,250$ & 1.05 & $48.58^{*}$ \\
\hline & $\begin{array}{l}\text { d) Manufacture of } \\
\text { Other Food Products }\end{array}$ & $6,54,236$ & $6,47,822$ & $6,45,164$ & $6,51,600$ & $6,85,304$ & 1.98 & $68.91^{*}$ \\
\hline & $\begin{array}{l}\text { e) Manufacture of } \\
\text { Beverages }\end{array}$ & 38,238 & 89,569 & 73,735 & 29,253 & 54,464 & 3.95 & $31.79^{*}$ \\
\hline 2 & $\begin{array}{l}\text { Manufacture of } \\
\text { Tobacco products }\end{array}$ & $\begin{array}{c}4,75,698 \\
(14.30) \\
\end{array}$ & $\begin{array}{c}4,23,567 \\
(12.18) \\
\end{array}$ & $\begin{array}{c}\mathbf{5 , 1 0 , 2 5 4} \\
(14.37) \\
\end{array}$ & $\begin{array}{c}5,35,644 \\
(14.36) \\
\end{array}$ & $\begin{array}{l}\mathbf{5 , 6 5 , 9 8 7} \\
(15.25) \\
\end{array}$ & 0.70 & $135.80^{*}$ \\
\hline \multirow[t]{4}{*}{3} & $\begin{array}{l}\text { Manufacture of } \\
\text { Textiles }\end{array}$ & $\begin{array}{c}12,64,589 \\
(38.01)\end{array}$ & $\begin{array}{c}13,65,822 \\
(39.29)\end{array}$ & $\begin{array}{c}12,85,922 \\
(36.23) \\
\end{array}$ & $13,74,300$ & $\begin{array}{l}13,25,809 \\
(35.73)\end{array}$ & 0.14 & $55.19^{*}$ \\
\hline & $\begin{array}{l}\text { a) Spinning, } \\
\text { Weaving \& Finishing } \\
\text { Textiles }\end{array}$ & $9,95,877$ & $9,75,698$ & $10,25,879$ & $10,65,282$ & $10,68,985$ & 2.81 & $40.54^{*}$ \\
\hline & $\begin{array}{l}\text { b) Manufacture of } \\
\text { Other Textiles }\end{array}$ & $1,12,788$ & $1,83,524$ & $1,52,685$ & $1,67,800$ & $1,07,222$ & 7.69 & $15.77^{*}$ \\
\hline & $\begin{array}{l}\text { c) Manufacture of } \\
\text { Knitted and } \\
\text { Crocheted Fabrics } \\
\text { and Articles }\end{array}$ & $1,55,924$ & $2,06,600$ & $1,07,358$ & $1,41,218$ & $1,49,602$ & 19.13 & $6.86^{*}$ \\
\hline \multirow[t]{3}{*}{4} & $\begin{array}{l}\text { Manufacture of } \\
\text { Leather Products }\end{array}$ & $\begin{array}{c}1,42,988 \\
(4.22)\end{array}$ & $\begin{array}{c}1,52,641 \\
(4.39)\end{array}$ & $\begin{array}{c}1,66,840 \\
(4.70)\end{array}$ & $\begin{array}{c}1,74,590 \\
(4.68)\end{array}$ & $\begin{array}{l}1,65,900 \\
(4.47)\end{array}$ & 6.71 & $17.58^{*}$ \\
\hline & $\begin{array}{l}\text { a) Manufacture of } \\
\text { hats and caps from } \\
\text { waterproof }\end{array}$ & 54,522 & 54,169 & 55,400 & 55,689 & 56,100 & 0.31 & $80.37^{*}$ \\
\hline & $\begin{array}{l}\text { b) Manufacture of } \\
\text { wearing apparel of } \\
\text { leather and } \\
\text { substitutes of leather }\end{array}$ & 88,466 & 98,472 & $1,14,440$ & $1,18,901$ & $1,09,800$ & 11.68 & $11.31^{*}$ \\
\hline \multirow[t]{2}{*}{5} & $\begin{array}{l}\text { Manufacture of } \\
\text { Paper \& Paper } \\
\text { Products }\end{array}$ & $\begin{array}{c}1,77,891 \\
(5.34)\end{array}$ & $\begin{array}{c}\mathbf{1 , 8 8 , 5 9 0} \\
(\mathbf{5 . 4 2 )}\end{array}$ & $\begin{array}{l}2,10,200 \\
(5.92)\end{array}$ & $\begin{array}{l}2,45,630 \\
\quad(6.58)\end{array}$ & $\begin{array}{l}2,42,561 \\
(6.53)\end{array}$ & 0.20 & 88.10 \\
\hline & Total & $\begin{array}{c}33,26,288 \\
(100.00)\end{array}$ & $\begin{array}{c}34,76,243 \\
(100.00)\end{array}$ & $\begin{array}{c}35,49,060 \\
(100.00)\end{array}$ & $\begin{array}{c}37,28,734 \\
(100.00)\end{array}$ & $\begin{array}{l}\mathbf{3 7 , 1 0 , 3 5 9} \\
(\mathbf{1 0 0 . 0 0 )}\end{array}$ & 0.60 & $155.85^{*}$ \\
\hline
\end{tabular}

(Table' $t$ ' value $=2.348$ )

* Significant at 1 per cent level

Note : Percentages in parentheses

Source: 1. Annual Survey of Industries, Central Statistical Organisation, New Delhi. (Different issues).

2. www.indiastat.com 


\section{CATEGORY-WISE EMPLOYMENT IN AGRO-BASED INDUSTRIES IN INDIA (Rs. in Lakhs)}

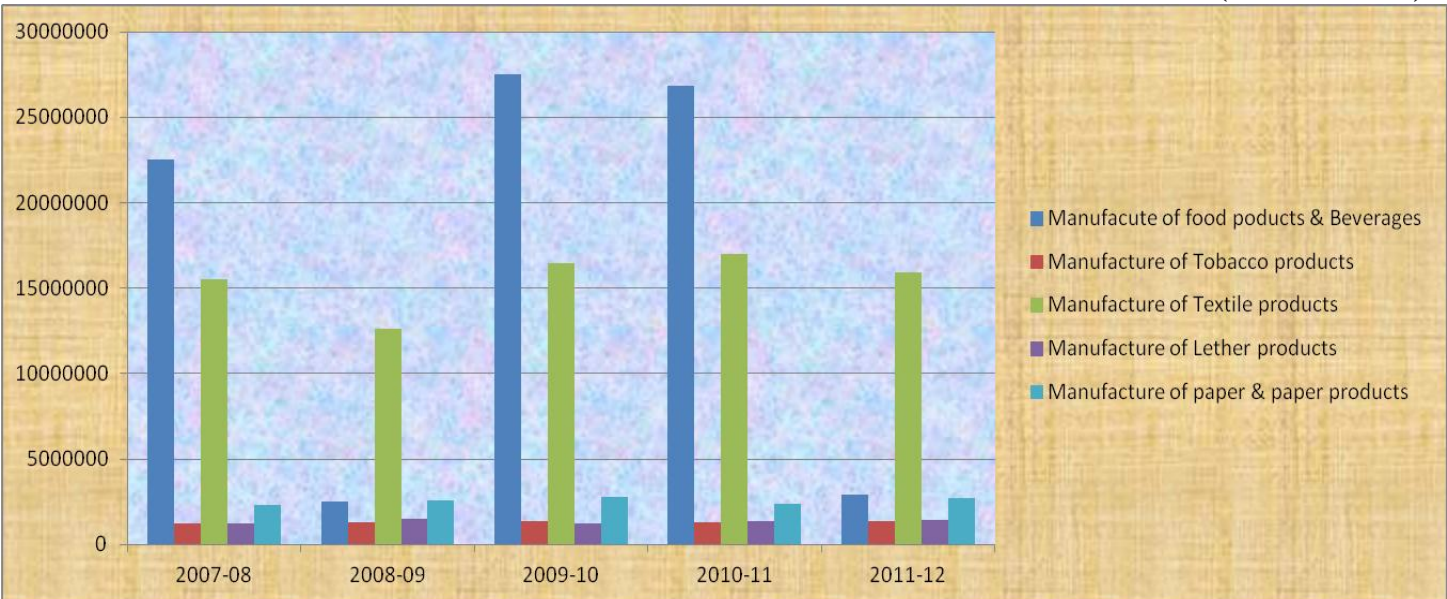

Source: 1. Annual Survey of Industries, Central Statistical Organisation, New Delhi. (Different issues)

2. www.indiastat.com

\section{The Category-wise Value of Output in Agro-Based Industries}

It is evident from Table 4.5 that the value of output of agro-based industries increased from Rs.4,28,70,962 lakhs in 2007-08 to Rs.5,03,36,888 lakhs in 2011-12 with a growth of 34.5 per cent. Among the different categories, the value of output is the highest in the case of manufacture of food products and beverages i.e. 57.4 per cent, and the lowest in manufacture of leather products i.e., 2.88 per cent, during the year 2011-12. The category-wise value of output is shown in the diagram. The Compound Growth Rates were significant at one per cent level for all the categories of agro-based industries over a period of five years from 2007-08 to 2011-12.

\section{Category-wise Net Value Added of Agro-Based Industries}

The net value added of food products and beverages has decreased from 38.64 percentage to 37.95 percentage during the period from 2007-08 to 2011-12, but its share of value added is the highest in total agrobased industries in all the years. In the case of textiles, the share of the net value added share to the total agrobased industries has increased from Rs. 14,66,825 lakhs $t$ to Rs. 15,29,743 lakhs in the same period. The net value added is the lowest in the case of leather products. All the categories of agro-based industries are significant at one per cent level based on the computed Compound Growth Rate and t-statistic figures.

\section{Category-wise Net Income of Agro-Based Industries}

The net income has increased from Rs.33,74,055 lakhs to Rs. 38,74,021 lakhs over a period of five years. During the year 2011-12, the manufacture of food products and beverages and manufacture of textiles generated more income i.e. Rs.12,55,136lakhs to Rs. 13,29,133 lakhs respectively in the total income generated by agro-based industries in India. The other three categories put together generated a net income of 27 per cent which is less than the net income of food products and textiles. The computed Compound Growth Rates reveal that the significant position of all the categories of Agro-Based Industries.

\section{CATEGORY-WISE VALUE OF OUTPUT OF AGRO-BASED INDUSTRIES IN} INDIA (Rs. in Lakhs)

\begin{tabular}{|c|c|c|c|c|c|c|c|c|}
\hline $\begin{array}{c}\text { Sl. } \\
\text { No } \\
\text {. }\end{array}$ & Category & 2007-08 & 2008-09 & 2009-10 & 2010-11 & 2011-12 & CGR & t-Stat \\
\hline \multirow[t]{4}{*}{1} & $\begin{array}{l}\text { Manufacture of } \\
\text { food products \& } \\
\text { Beverages }\end{array}$ & $\begin{array}{c}2,25,36,652 \\
(52.56)\end{array}$ & $\begin{array}{c}2,52,35,987 \\
(\mathbf{5 8 . 4 3 )}\end{array}$ & $\begin{array}{c}2,74,89,300 \\
(55.69)\end{array}$ & $\begin{array}{c}2,68,25,901 \\
(54.83)\end{array}$ & $\begin{array}{c}2,88,96,388 \\
(57.40)\end{array}$ & 7.22 & $15.29^{*}$ \\
\hline & $\begin{array}{l}\text { a) Production, } \\
\text { Processing \& } \\
\text { Preservation of } \\
\text { Meat, Fish, Fruit, } \\
\text { Oil \& Fats }\end{array}$ & $63,25,855$ & $64,52,400$ & $67,82,985$ & $69,50,200$ & $65,29,818$ & 16.43 & $11.69^{*}$ \\
\hline & $\begin{array}{l}\text { b) Manufacture of } \\
\text { Dairy Products }\end{array}$ & $23,84,577$ & $24,51,600$ & $25,49,677$ & $24,10,752$ & $28,54,861$ & 5.54 & $22.84^{*}$ \\
\hline & $\begin{array}{l}\text { c) Manufacture of } \\
\text { Grain Mill } \\
\text { Products, Starches } \\
\text { \& Starch Products }\end{array}$ & $52,33,788$ & $54,87,566$ & $55,41,711$ & $58,44,910$ & $56,28,188$ & 9.47 & $13.81^{*}$ \\
\hline
\end{tabular}


Performance Of Agro-Based Industries In India: A Critical Analysis

\begin{tabular}{|c|c|c|c|c|c|c|c|c|}
\hline $\begin{array}{c}\text { Sl. } \\
\text { No } \\
\text {. }\end{array}$ & Category & 2007-08 & 2008-09 & 2009-10 & 2010-11 & 2011-12 & CGR & t-Stat \\
\hline & $\begin{array}{l}\text { and Prepared } \\
\text { Animal Feeds }\end{array}$ & & & & & & & \\
\hline & $\begin{array}{l}\text { d) Manufacture of } \\
\text { Other Food } \\
\text { Products }\end{array}$ & $51,23,844$ & $51,24,800$ & $52,94,751$ & $56,24,100$ & $55,84,945$ & 0.47 & $52.56^{*}$ \\
\hline & $\begin{array}{l}\text { e) Manufacture of } \\
\text { Beverages }\end{array}$ & $34,68,588$ & $57,19,621$ & $73,20,176$ & $59,95,939$ & $82,98,576$ & 11.12 & $13.17^{*}$ \\
\hline 2 & $\begin{array}{l}\text { Manufacture of } \\
\text { Tobacco } \\
\text { products }\end{array}$ & $\begin{array}{c}12,57,598 \\
(2.93)\end{array}$ & $\begin{array}{c}12,65,274 \\
(2.92)\end{array}$ & $\begin{array}{c}13,69,844 \\
(2.77)\end{array}$ & $\begin{array}{c}13,25,101 \\
(2.70)\end{array}$ & $\begin{array}{c}13,75,589 \\
(2.81)\end{array}$ & 2.67 & $23.20^{*}$ \\
\hline \multirow[t]{4}{*}{3} & $\begin{array}{l}\text { Manufacture of } \\
\text { Textiles }\end{array}$ & $\begin{array}{c}1,55,25,366 \\
(36.21)\end{array}$ & $\begin{array}{c}1,25,87,500 \\
(29.14)\end{array}$ & $\begin{array}{c}1,64,87,911 \\
(33.40)\end{array}$ & $\begin{array}{c}1,70,25,608 \\
(34.80)\end{array}$ & $\begin{array}{c}1,59,29,212 \\
(31.64)\end{array}$ & 5.86 & $19.87^{*}$ \\
\hline & $\begin{array}{l}\text { a) Spinning, } \\
\text { Weaving \& } \\
\text { Finishing Textiles }\end{array}$ & $87,99,582$ & $84,26,200$ & $89,28,769$ & $89,65,500$ & $87,51,909$ & 4.07 & $24.93^{*}$ \\
\hline & $\begin{array}{l}\text { b) Manufacture of } \\
\text { Other Textiles }\end{array}$ & $11,25,845$ & $11,59,900$ & $12,76,918$ & $13,85,937$ & $13,82,365$ & 17.44 & $7.52^{*}$ \\
\hline & $\begin{array}{l}\text { c) Manufacture of } \\
\text { Knitted and } \\
\text { Crocheted Fabrics } \\
\text { and Articles }\end{array}$ & $55,99,669$ & $30,01,400$ & $62,82,224$ & 6674171 & $57,94,938$ & 12.72 & $9.17^{*}$ \\
\hline \multirow[t]{3}{*}{4} & $\begin{array}{l}\text { Manufacture of } \\
\text { Leather } \\
\text { Products }\end{array}$ & $\begin{array}{c}12,52,969 \\
(2.92)\end{array}$ & $\begin{array}{c}15,28,233 \\
(3.53)\end{array}$ & $\begin{array}{c}12,59,188 \\
(2.55)\end{array}$ & $\begin{array}{c}13,84,142 \\
(2.82)\end{array}$ & $\begin{array}{c}14,51,299 \\
(2.88)\end{array}$ & 5.33 & $25.19^{*}$ \\
\hline & $\begin{array}{l}\text { a) Manufacture of } \\
\text { hats and caps } \\
\text { from waterproof }\end{array}$ & $5,48,266$ & $5,42,829$ & $5,98,266$ & $5,46,874$ & $5,65,255$ & 7.26 & $18.67^{*}$ \\
\hline & $\begin{array}{l}\text { b) Manufacture of } \\
\text { wearing apparel } \\
\text { of leather and } \\
\text { substitutes of } \\
\text { leather }\end{array}$ & $7,04,703$ & $9,85,404$ & $6,60,922$ & $8,37,268$ & $8,86,044$ & 3.76 & $23.48^{*}$ \\
\hline \multirow[t]{2}{*}{5} & $\begin{array}{l}\text { Manufacture of } \\
\text { Paper \& Paper } \\
\text { Products }\end{array}$ & $\begin{array}{c}22,98,377 \\
(5.36)\end{array}$ & $\begin{array}{c}25,68,900 \\
(5.94)\end{array}$ & $\begin{array}{c}27,51,200 \\
\quad(5.57)\end{array}$ & $\begin{array}{c}23,58,568 \\
(4.82)\end{array}$ & $\begin{array}{c}26,84,400 \\
(5.33) \\
\end{array}$ & 5.72 & $21.46^{*}$ \\
\hline & Total & $\begin{array}{c}4,28,70,962 \\
(100.00)\end{array}$ & 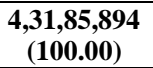 & $\begin{array}{c}4,93,57,443 \\
(100.00)\end{array}$ & $\begin{array}{c}, 89,19,200 \\
(100.00)\end{array}$ & $\begin{array}{c}5,03,36,888 \\
(100.00)\end{array}$ & 7.64 & $19.25^{*}$ \\
\hline
\end{tabular}

(Table' $t$ ' value $=2.365) \quad *$ Significant at 1 per cent level Note $:$ Percentages in parentheses

Source: 1. Annual Survey of Industries, Central Statistical Organisation, New Delhi. (Differentsues)

2. www.indiastat.com

\section{CATEGORY-WISE VALUE OF OUTPUT OF AGRO-BASED INDUSTRIES IN INDIA (Rs. in Lakhs)}

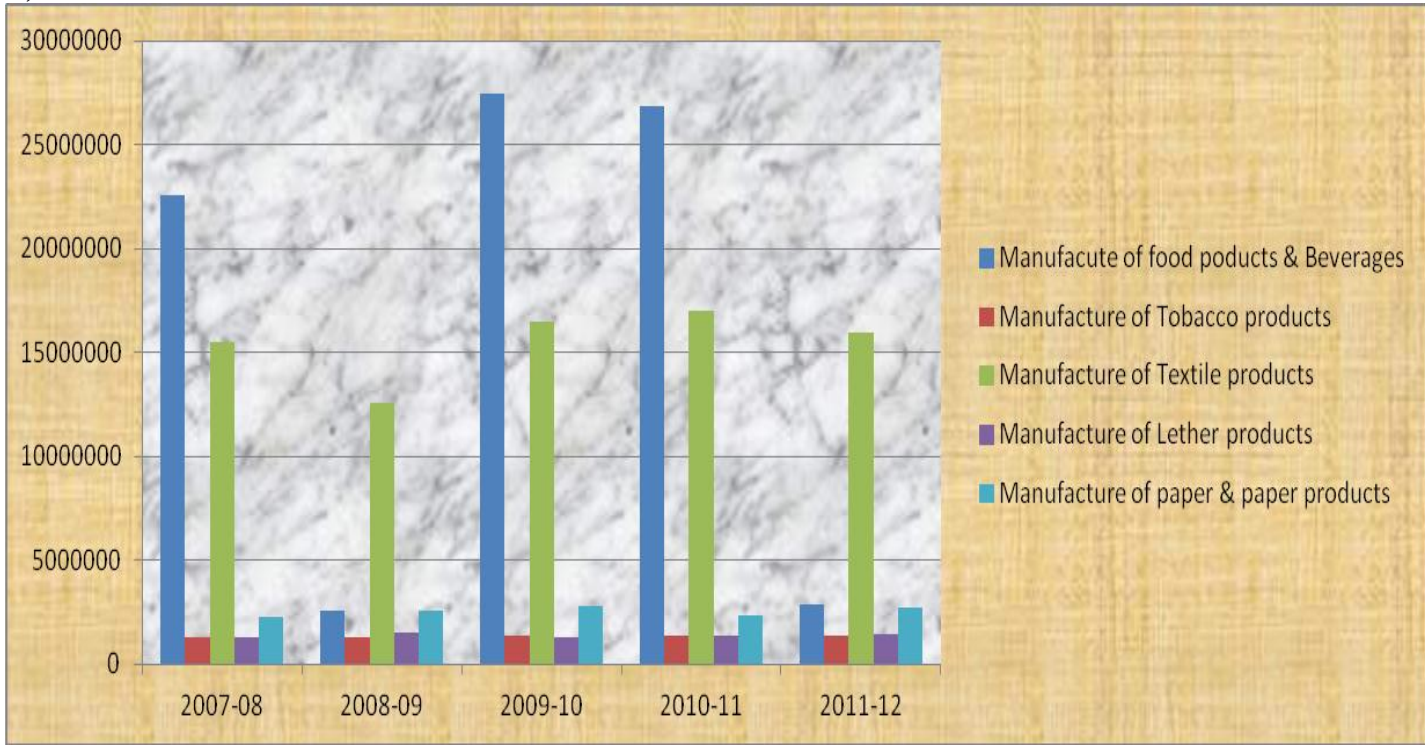

Source: 1. Annual Survey of Industries, Central Statistical Organisation, New Delhi. (Different issues). 2. www.indiastat.com 
Performance Of Agro-Based Industries In India: A Critical Analysis

CATEGORY WISE NET VALUE ADDED OF AGRO-BASED INDUSTRIES IN INDIA

(Rs. in Lakhs)

\begin{tabular}{|c|c|c|c|c|c|c|c|c|}
\hline $\begin{array}{l}\text { Sl. } \\
\text { No. }\end{array}$ & Category & 2007-08 & 2008-09 & 2009-10 & 2010-11 & 2011-12 & CGR & t-Stat \\
\hline \multirow[t]{6}{*}{1} & $\begin{array}{l}\text { Manufacture of } \\
\text { food products \& } \\
\text { Beverages }\end{array}$ & $\begin{array}{c}15,61,20 \\
0 \\
(38.64) \\
\end{array}$ & $\begin{array}{c}15,68,91 \\
2 \\
(38.22) \\
\end{array}$ & $\begin{array}{c}16,02,34 \\
6 \\
(38.34) \\
\end{array}$ & $\begin{array}{c}16,49,500 \\
(38.04)\end{array}$ & $\begin{array}{c}\mathbf{1 6 , 8 8 , 3 7 9} \\
(37.95)\end{array}$ & 0.59 & $69.84^{*}$ \\
\hline & $\begin{array}{l}\text { a) Production, } \\
\text { Processing \& } \\
\text { Preservation of Meat, } \\
\text { Fish, Fruit, Oil \& } \\
\text { Fats }\end{array}$ & $2,84,591$ & $2,96,288$ & $3,15,871$ & $3,45,129$ & $3,52,853$ & 7.66 & $17.86^{*}$ \\
\hline & $\begin{array}{l}\text { b) Manufacture of } \\
\text { Dairy Products }\end{array}$ & $2,19,145$ & $2,19,552$ & $2,44,581$ & $2,67,829$ & $2,88,389$ & 1.38 & $51.62^{*}$ \\
\hline & $\begin{array}{l}\text { c) Manufacture of } \\
\text { Grain Mill Products, } \\
\text { Starches \& Starch } \\
\text { Products and } \\
\text { Prepared Animal } \\
\text { Feeds }\end{array}$ & 37,560 & 39,522 & 41,578 & 39,855 & 46,200 & 31.52 & $4.45^{*}$ \\
\hline & $\begin{array}{l}\text { d) Manufacture of } \\
\text { Other Food Products }\end{array}$ & $7,68,460$ & $7,84,210$ & $7,69,273$ & $8,02,766$ & $7,82,391$ & 1.61 & $22.35^{*}$ \\
\hline & $\begin{array}{l}\text { e) Manufacture of } \\
\text { Beverages }\end{array}$ & $2,51,442$ & $2,29,340$ & $2,31,043$ & $1,93,921$ & $2,81,546$ & 6.39 & $10.21^{*}$ \\
\hline 2 & $\begin{array}{l}\text { Manufacture of } \\
\text { Tobacco products }\end{array}$ & $\begin{array}{c}4,98,661 \\
(12.34)\end{array}$ & $\begin{array}{c}5,25,300 \\
(12.79)\end{array}$ & $\begin{array}{c}5,48,796 \\
(13.13)\end{array}$ & $\begin{array}{c}5,74,267 \\
(13.24)\end{array}$ & $\begin{array}{c}5,94,289 \\
(13.36)\end{array}$ & 6.30 & $20.58^{*}$ \\
\hline \multirow[t]{4}{*}{3} & $\begin{array}{l}\text { Manufacture of } \\
\text { Textiles }\end{array}$ & $\begin{array}{c}14,66,82 \\
5 \\
(36.30) \\
\end{array}$ & $\begin{array}{c}14,75,20 \\
0 \\
(35.94) \\
\end{array}$ & $\begin{array}{c}14,84,86 \\
0 \\
(35.53) \\
\end{array}$ & $\begin{array}{c}14,98,264 \\
(34.56)\end{array}$ & $\begin{array}{c}15,29,743 \\
(34.39)\end{array}$ & 4.49 & $19.95^{*}$ \\
\hline & $\begin{array}{l}\text { a) Spinning, } \\
\text { Weaving \& Finishing } \\
\text { Textiles }\end{array}$ & $\begin{array}{c}12,35,86 \\
3\end{array}$ & $\begin{array}{c}12,59,25 \\
4\end{array}$ & $\begin{array}{c}12,45,68 \\
3\end{array}$ & $12,18,300$ & $12,41,875$ & 3.18 & $24.01^{*}$ \\
\hline & $\begin{array}{l}\text { b) Manufacture of } \\
\text { Other Textiles }\end{array}$ & $1,60,584$ & $1,55,294$ & $1,64,200$ & $1,78,912$ & $1,88,954$ & 10.04 & $13.05^{*}$ \\
\hline & $\begin{array}{l}\text { c) Manufacture of } \\
\text { Knitted and } \\
\text { Crocheted Fabrics } \\
\text { and Articles }\end{array}$ & 70,378 & 60,652 & 74,977 & $1,01,052$ & 98,914 & 11.76 & $9.24^{*}$ \\
\hline \multirow[t]{3}{*}{4} & $\begin{array}{l}\text { Manufacture of } \\
\text { Leather Products }\end{array}$ & $\begin{array}{c}1,44,856 \\
(3.58) \\
\end{array}$ & $\begin{array}{c}1,46,285 \\
(3.56) \\
\end{array}$ & $\begin{array}{c}1,53,893 \\
(3.68) \\
\end{array}$ & $\begin{array}{c}1,55,890 \\
(3.59)\end{array}$ & $\begin{array}{c}2,10,542 \\
(4.73)\end{array}$ & 4.53 & $28.58^{*}$ \\
\hline & $\begin{array}{l}\text { a) Manufacture of } \\
\text { hats and caps from } \\
\text { waterproof }\end{array}$ & 48,922 & 49,873 & 46,859 & 47,598 & 48,884 & 7.16 & $16.86^{*}$ \\
\hline & $\begin{array}{l}\text { b) Manufacture of } \\
\text { wearing apparel of } \\
\text { leather and } \\
\text { substitutes of leather }\end{array}$ & 95,934 & 96,412 & $1,07,034$ & $1,08,292$ & $1,61,658$ & 1.77 & $40.37^{*}$ \\
\hline \multirow[t]{2}{*}{5} & $\begin{array}{l}\text { Manufacture of } \\
\text { Paper \& Paper } \\
\text { Products } \\
\end{array}$ & $\begin{array}{c}3,68,225 \\
(9.11)\end{array}$ & $\begin{array}{c}\mathbf{3 , 8 8 , 7 9 2} \\
(\mathbf{9 . 4 7 )}\end{array}$ & $\begin{array}{c}3,89,241 \\
(9.31)\end{array}$ & $\begin{array}{c}4,56,296 \\
(10.54)\end{array}$ & $\begin{array}{l}4,25,126 \\
(9.55)\end{array}$ & 0.55 & $22.42^{*}$ \\
\hline & Total & $\begin{array}{c}40,39,76 \\
7 \\
(100.00) \\
\end{array}$ & $\begin{array}{c}41,04,48 \\
9 \\
(100.00) \\
\end{array}$ & $\begin{array}{c}41,79,13 \\
6 \\
(100.00) \\
\end{array}$ & $\begin{array}{c}43,34,217 \\
(100.00)\end{array}$ & $\begin{array}{c}44,48,079 \\
(100.00)\end{array}$ & 2.03 & $49.67^{*}$ \\
\hline
\end{tabular}

Note : Percentages in parentheses (Table ‘ $t$ ' value $=2.365)^{*}$ Significant at 1 per cent level

Source: 1. Annual Survey of Industries, Central Statistical Organisation, New Delhi. (Different issues).

2. www.indiastat.com 


\section{CATEGORY WISE NET VALUE ADDED OF AGRO-BASED INDUSTRIES IN INDIA}

(Rs. in Lakhs)

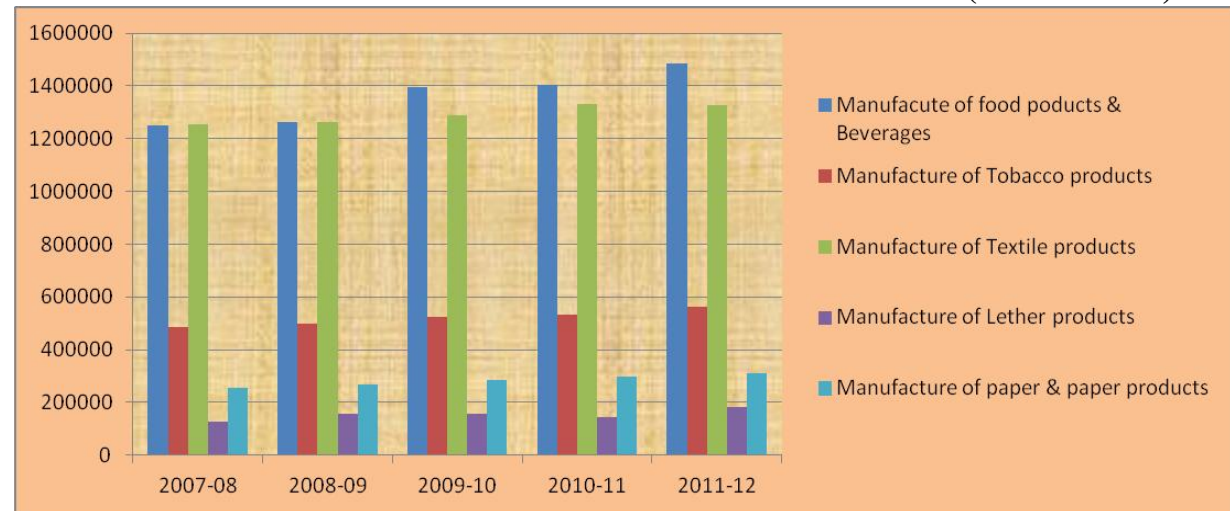

Source: 1. Annual Survey of Industries, Central Statistical Organisation, New Delhi.

(Different issues).

2. www.indiastat.com

\section{CATEGORY WISE NET INCOME OF AGRO-BASED INDUSTRIES IN INDIA}

\begin{tabular}{|c|c|c|c|c|c|c|c|c|}
\hline $\begin{array}{l}\text { Sl. } \\
\text { No } \\
\text {. }\end{array}$ & Category & 2007-08 & 2008-09 & 2009-10 & $2010-11$ & 2011-12 & CGR & t-Stat \\
\hline \multirow[t]{6}{*}{1} & $\begin{array}{l}\text { Manufacture of food } \\
\text { products \& Beverages }\end{array}$ & $\begin{array}{c}12,52,467 \\
(37.09)\end{array}$ & $\begin{array}{c}12,61,70 \\
3 \\
(36.54) \\
\end{array}$ & $\begin{array}{c}13,94,528 \\
(38.20)\end{array}$ & $\begin{array}{c}14,02,528 \\
(37.80)\end{array}$ & $\begin{array}{c}\mathbf{1 4 , 8 6 , 8 5 4} \\
(38.38)\end{array}$ & 6.84 & $11.52^{*}$ \\
\hline & $\begin{array}{l}\text { a) Production, } \\
\text { Processing \& } \\
\text { Preservation of Meat, } \\
\text { Fish, Fruit, Oil \& Fats }\end{array}$ & $2,15,642$ & $2,45,834$ & $2,57,800$ & $2,59,670$ & $3,01,120$ & 12.43 & $14.28^{*}$ \\
\hline & $\begin{array}{l}\text { b) Manufacture of Dairy } \\
\text { Products }\end{array}$ & $1,95,284$ & $2,17,840$ & $2,35,608$ & $2,85,200$ & $2,75,366$ & 8.67 & $2.63^{*}$ \\
\hline & $\begin{array}{l}\text { c) Manufacture of Grain } \\
\text { Mill Products, Starches } \\
\text { \& Starch Products and } \\
\text { Prepared Animal Feeds }\end{array}$ & $2,86,419$ & $2,17,824$ & $2,94,400$ & $3,10,800$ & $3,20,970$ & 10.44 & $9.07^{*}$ \\
\hline & $\begin{array}{l}\text { d) Manufacture of Other } \\
\text { Food Products }\end{array}$ & $4,22,845$ & $4,68,210$ & $4,70,610$ & $4,46,800$ & $4,74,921$ & 2.87 & $9.24^{*}$ \\
\hline & $\begin{array}{l}\text { e) Manufacture of } \\
\text { Beverages }\end{array}$ & $1,32,277$ & $1,11,979$ & $1,36,110$ & $1,00,058$ & $1,14,477$ & 9.25 & $7.21^{*}$ \\
\hline 2 & $\begin{array}{l}\text { Manufacture of } \\
\text { Tobacco products }\end{array}$ & $\begin{array}{c}\mathbf{4 , 8 6 , 2 9 7} \\
(14.40) \\
\end{array}$ & $\begin{array}{c}4,99,874 \\
(14.48) \\
\end{array}$ & $\begin{array}{c}5,26,500 \\
(14.42)\end{array}$ & $\begin{array}{c}5,32,810 \\
(14.36)\end{array}$ & $\begin{array}{c}5,64,910 \\
(14.58)\end{array}$ & 7.32 & $16.71^{*}$ \\
\hline \multirow[t]{4}{*}{3} & $\begin{array}{l}\text { Manufacture of } \\
\text { Textiles }\end{array}$ & $\begin{array}{c}12,55,138 \\
(37.17)\end{array}$ & $\begin{array}{c}12,64,97 \\
5 \\
(36.64) \\
\end{array}$ & $\begin{array}{l}\mathbf{1 2 , 8 8 , 4 1 0} \\
(35.29)\end{array}$ & $\begin{array}{c}13,30,800 \\
(35.86)\end{array}$ & $\begin{array}{c}13,29,133 \\
(34.30)\end{array}$ & 12.23 & $10.27^{*}$ \\
\hline & $\begin{array}{l}\text { a) Spinning, Weaving } \\
\text { \& Finishing Textiles }\end{array}$ & $7,77,215$ & $7,24,133$ & $8,04,200$ & $8,56,352$ & $8,94,285$ & 11.01 & $9.50^{*}$ \\
\hline & $\begin{array}{l}\text { b) Manufacture of } \\
\text { Other Textiles }\end{array}$ & $1,36,966$ & $1,32,889$ & $1,39,008$ & $1,45,800$ & $1,92,000$ & 13.33 & $9.37^{*}$ \\
\hline & $\begin{array}{l}\text { c) Manufacture of } \\
\text { Knitted and Crocheted } \\
\text { Fabrics and Articles }\end{array}$ & $3,40,957$ & $4,07,953$ & $3,45,202$ & $3,28,648$ & $2,42,848$ & 12.98 & $8.30^{*}$ \\
\hline \multirow[t]{3}{*}{4} & $\begin{array}{l}\text { Manufacture of } \\
\text { Leather Products }\end{array}$ & $\begin{array}{c}1,26,310 \\
(3.74) \\
\end{array}$ & $\begin{array}{c}1,55,900 \\
(4.51)\end{array}$ & $\begin{array}{c}1,56,284 \\
(4.28) \\
\end{array}$ & $\begin{array}{c}, 44,988 \\
(3.90) \\
\end{array}$ & $\begin{array}{c}1,82,600 \\
(4.71)\end{array}$ & 6.17 & $20.77^{*}$ \\
\hline & $\begin{array}{l}\text { a) Manufacture of hats } \\
\text { and caps from } \\
\text { waterproof }\end{array}$ & 41,580 & 43,980 & 48,290 & 49,320 & 50,124 & 11.89 & $10.67^{*}$ \\
\hline & $\begin{array}{l}\text { b) Manufacture of } \\
\text { wearing apparel of } \\
\text { leather and substitutes of } \\
\text { leather }\end{array}$ & 84,730 & $1,11,920$ & $1,07,994$ & 95,668 & $1,32,476$ & 3.64 & $29.33^{*}$ \\
\hline \multirow[t]{2}{*}{5} & $\begin{array}{l}\text { Manufacture of Paper } \\
\text { \& Paper Products }\end{array}$ & $\begin{array}{c}2,55,843 \\
(7.57) \\
\end{array}$ & $\begin{array}{c}2,69,840 \\
(7.81) \\
\end{array}$ & $\begin{array}{c}2,84,389 \\
(7.79) \\
\end{array}$ & $\begin{array}{c}2,99,200 \\
(8.06) \\
\end{array}$ & $\begin{array}{c}3,10,524 \\
(8.01) \\
\end{array}$ & 3.65 & $12.43^{*}$ \\
\hline & Total & $33,76,055$ & $\begin{array}{c}34,52,29 \\
2\end{array}$ & $36,50,111$ & $37,10,326$ & $38,74,021$ & 8.97 & 15.28 \\
\hline
\end{tabular}

(Table't' value $=2.455)^{*}$ Significant at 1 per cent level

@ Not significant at 5 per cent level Note :

Percentages in parentheses 
Source: 1. Annual Survey of Industries, Central Statistical Organisation, New Delhi. (Different issues).

2. www.indiastat.com

\section{CATEGORY WISE NET INCOME OF AGRO-BASED INDUSTRIES IN INDIA}

(Rs. in Lakhs)

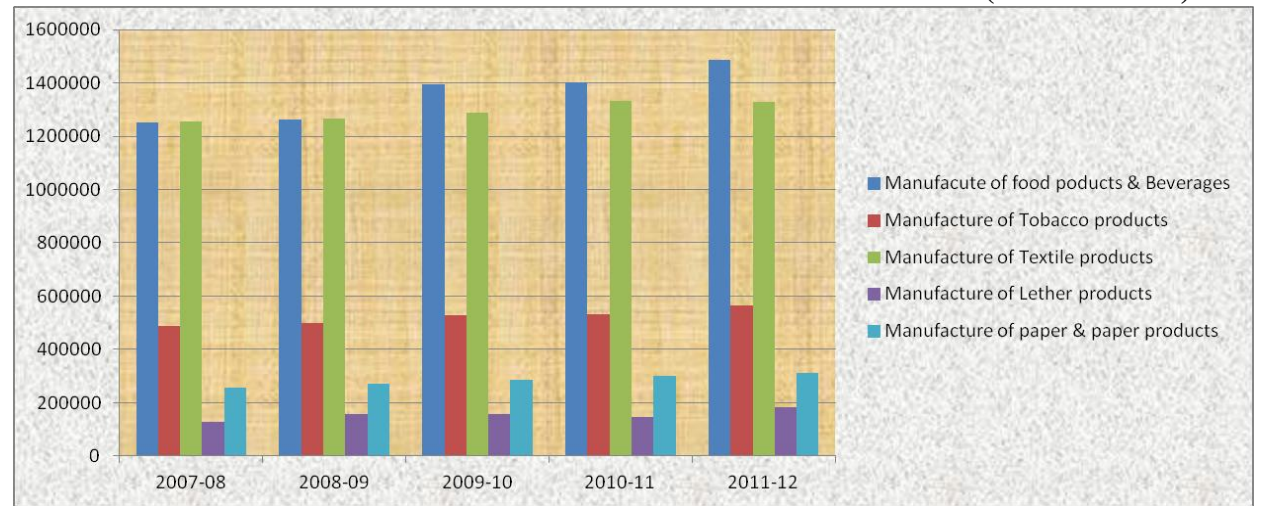

Source: 1. Annual Survey of Industries, Central Statistical Organisation, New Delhi. (Different issues).

2. www.indiastat.com

[1]. “The Financial Express", Bombay, June 23, 1975

[2]. Badar A. Iqbal., (1981), "Agro-Based Industries: Performance and Prospects", Printwell Publishers, p.3.

[3]. Desai P.B., (1986), "Relevance of Population Change for Balanced Development of Industry and Agriculture", World Economic Congress New Delhi, Vol. 17, p.14.

[4]. Venkaiah V., (1987), "Impact of Agro-Based Industries on Rural Economy", Himalaya Publishing House, Bombay, p.18.

[5]. Government of India, (1977), "Small Scale Industries Development Commission", New Delhi, p.61.

[6]. Badar A. Iqbal., (1980), "Financing of Agro-Industrial Development in India", p. 2-3.

[7]. Bhattacharya S.N., (1980), "Rural Industrialisation in India: Its Nature and problems", B. R. Publishing Corporation, New Delhi, p.102.

[8]. Gunnar Myrdal., (1968), "Asian Drama", London, vol. II, p.1029.

[9]. Thakur S.Y., (1985), "Rural Industrialisation in India", Sterling Publishers, New Delhi, p.124.

[10]. Gupta S.K., (1993), "Development of Agro-based industries: Problems and Prospects", Deep and Deep Publications, New Delhi, p.49.

[11]. Ramakrishna K.T., "Finances for Small Scale Industries in India”, Asia Publishing House, New Delhi, p.1.

[12]. Gurumohan Reddy M., Gunasekar B., and Karimulla SK., (2006), "Agro - Rural Industry and Performance in Planning Era" Paper submitted at National Seminar on "Role of Indian Agro-Industry in Rural Economic Development - A Perspective" at Sri Venkateswara College, Suryapet, Nalgonda, Andhra Pradesh.

[13]. First Five Year Plan, 1951-56, Government of India

[14]. Second Five Year Plan, 1956-61, Government of India.

[15]. Third Five Year Plan, 1961-66, Government of India.

[16]. Fourth Five Year Plan, 1969-74, Government of India.

[17]. Fifth Five Year Plan, 1974-79, Government of India.

[18]. Sixth Five Year Plan, 1980-85, Government of India.

[19]. Seventh Five Year Plan, 1985-90, Government of India.

[20]. Eighth Five Year Plan, 1992-97, Government of India.

[21]. Ninth Five Year Plan, 1997-02, Government of India.

[22]. Tenth Five Year Plan, 2002-07, Government of India.

[23]. Eleventh Five Year Plan, 2007-12, Government of India.

[24]. Annual Survey of Industries, (2000-05), Central Statistical Organisation, New Delhi. (Different issues).

[25]. www.indiastat.com.

[26]. AmarnathBandarla., (1992), "Problems of Agro-Based Industries", National Bank-News Review, Vol. 8, No.1, pp. 27-29.

[27]. Devraja T.S (2009),"Financial performance of Agro Based Industries" AnmolPublications Pvt. Ltd., New Delhi.

[28]. Kar G.C and Mishra S.N. (2004), "Agro industries \& economic development”,Deep\& Deep publications pvt. Ltd.

[29]. KhajuriaMeenakhsi\&khajuria R.K. (2010)," Second Green Revolution- Prospects\& Challenges”, KurukshetraVol 58, No.5, March 2010, pp 19-20.

[30]. Mohanty B. K. (2010),” Agricultural Growth- It"s time for Gene Revolution”,Kurukshetra, Vol 58, No 9, March 2010, pp 3-4.

[31]. NayakPurusottam (1996)," Problems and Prospects of Agro based Industry: A Case Study",Journal of Assam University, Vol.1, No.1, 1996, pp 22-28.

[32]. PatroBhagabata and NayakPreyasi (2002), Employment Implications of Agro- based industries in India; Agro industries \& economic development; Deep \& Deep publications Pvt. Lt 